\title{
Makyavelist Kişilik Eğilimi Algılarının Yaşamın Anlamı ve Yaşam Doyumu Üzerine Etkisi
}

\author{
Altan AYAN*
}

\begin{abstract}
$\ddot{O} Z$
Çalışmada öncelikle kavramsal çerçeve açıklanmıştır. Daha sonra makyavelist kişilik eğilimi algılarının yaşamın anlamı ve yaşam doyumu üzerine etkisi incelenmiştir. Araştırmanın örneklemi, bir devlet üniversitesinin uygulamalı bilimler yüksekokullarında öğrenim gören 365 ögrencidir. Araştırmanın evreni, bu devlet üniversitesinde okuyan tüm ögrrencilerdir. Araştırmanın amacı, makyavelist kişilik eğilimi algılarının yaşamın anlamı ve yaşam doyumu üzerine etkisini incelemektir. Ayrıca, yaşamın anlamı düzeyinin yaşam doyumu üzerine etkisi de araştırılmıştır. Bu kapsamda frekans analizi, faktör analizi, güvenirlik testi, çoklu regresyon testi ve korelasyon analizi uygulanmıştır. Sonuç olarak, dürüst kişilik eğiliminin hem yaşamın anlamı alt boyutlarını hem de yaşam doyumunu arttırdiğı gözlenmiştir. Olumlu kişilik eğiliminin hem mevcut anlamı hem de yaşam

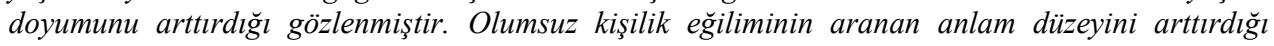
gözlenmiştir. Yaşamın anlamı düzeyi alt boyutlarının yaşam doyumunu arttırdı̆̆ gözlenmiștir. Ögrencileri

Anahtar Kelimeler: Makyavelist Kişilik, Yaşamın Anlamı, Yaşam Doyumu, Üniversite
\end{abstract}

JEL Sinıflandırması: M10, M12, M14

\section{The Effect of the Concepts of Machiavellian Personality Tendencies on Meaning in Life and Life Satisfaction}

ABSTRACT

In the study, firstly, the conceptual framework is expressed. Then a research is carried out on the effect of the concepts of Machiavellian personality tendencies on meaning in life and life satisfaction. The research sample comprises a total of 365 students from schools of applied sciences at a state university. The population of the research covers all students studying at this state university. The aim of this study is to examine the effect of the concepts of Machiavellian personality tendencies on meaning in life and life satisfaction. In addition, the effect of the level of meaning in life on life satisfaction is scrutinized. In this context, frequency analysis, factor analysis, reliability test, multiple regression tests and correlation analysis were carried out. Consequently, it has seen that honest personality tendency increases both the sub-dimensions of meaning in life and life satisfaction. It is observed that positive personality tendency increases both the presence of meaning and life satisfaction. On the other hand, it is observed that negative personality tendency increases the level of search of meaning. The sub-dimensions of the level of meaning in life have also been observed to increase life satisfaction. Students

Key Words: Machiavellian Personality, Meaning in Life, Life Satisfaction, University

JEL Classification: M10, M12, M14

*Yrd.Doç.Dr., Trakya Üniversitesi Uzunköprü Uygulamalı Bilimler Yüksekokulu, Halkla İlişkiler ve Reklamcılık Bölümü. altanayanayan@gmail.com 


\section{GİRIŞ}

Günümüz dünyasında pozitif psikoloji ile ilgili kavramlara artan bir ilgi mevcuttur. Yaşamın anlamı ve yaşam doyumu kavramları pozitif psikoloji paradigmasıyla birlikte öne çıkmıştır (Aktaş ve Şimşek, 2014; Şimşek ve Aktaş, 2014: 124). Yaşamın anlamı kavramı pozitif psikolojinin temel kavramlarından biridir. Yaşamın anlamı değişkeni ile zihinsel sağlık arasında pozitif bir ilişki vardır (Demirbaş Çelik ve İşmen Gazioğlu, 2015: 44; Mason, 2013: 635). Bu değişkenler kişilerin yaşamlarını etkileyen olumlu unsurlardır. Makyavelist kişilik eğilimi ise kişiler için olumsuz kabul edilen bir değişkendir. Bu kapsamda makyavelist kişilik eğiliminin, iki olumlu değişken olan yaşamın anlamı ve yaşam doyumu üzerine etki edip etmediğinin incelenmesi önemlidir. Makyavelist kişilik eğilimi algısının yaşamın anlamı ve yaşam doyumu üzerine etki edip etmediği araştırmada incelenmiştir. Ayrıca araştırmada yaşamın anlamı düzeyinin yaşam doyumu üzerine etkisi incelenmiştir. Araştırılan konunun uygulamasının üniversite öğrencileri üzerine yapılmış olması çalışmanın katkısı açısından önemlidir. Üniversite öğrencilerinin yaşamın anlamı ve yaşam doyumlarını arttıran veya azaltan değişkenlerin belirlenmesi sayesinde bu konularda çeşitli önlemler veya destekleyici faaliyetler geliştirilebilir.

\section{I.KAVRAMSAL ÇERÇEVE}

\section{A. Makyavelizm}

Makyavelizm, Niccolo Machiavelli'nin 16. Yüzyılda yazdıkları temelinde ortaya çıkmış bir düşüncedir. Niccolo Machiavelli tarafından 16. Yüzyılda yazılan "Prens (The Prince)" adlı eser, kişisel gücün kullanılarak amaçlara nasıl ulaşılacağını açıklamaktadır. Bu eserde çeşitli tutumlar, stratejiler ve taktikler de ifade edilmektedir. Makyavelizm kavramını manipülatif kişilik eğilimi veya kişinin manipülatif eğilimleri olarak da açıklamak mümkündür (Ayan, Ünsar ve Kahraman, 2013: 104-105). Makyavelizm düşüncesi, Machiavelli tarafindan oluşturulmuştur. Bu düşünceye göre amaca ulaşmak için kullanılan her yol ve yöntem kabul edilebilir görülmektedir. Makyavelizm, kişilerin istedikleri amaçlara ulaşması için diğer kişiler üzerinde yönlendirici etki oluşturan etik olmayan davranışları bütünüdür. Makyavelist kişilerin geleneksel ahlak anlayışına sahip olmadıkları söylenebilir (Güney ve Mandac1, 2009: 84-85). Makyavelistler, kendi amaçlarına ulaşmak için başkalarını manipüle etme isteği ve yeteneğine sahip kişilerdir. Bu kişiler etik normlara uygun hareket etmezler. Kendi faydalarına olacak şekilde insanları ve durumları beceriyle yönlendirebilecek stratejiler uygularlar (Becker ve Dan O'Hair, 2007: 248).

Makyavelist kişilik eğilimi, kişilerin çıkarları için başkalarını aldatma ve onları kendi istediği doğrultuda hareket ettirme becerisidir. Makyavelist kişiler, sadece kendi amaçlarını gerçekleştirmeye odaklanırlar. Bu kişiler iş ve sosyal hayatlarında güç ve statü elde etmek için etik olmayan davranışlar gösterebilirler (Kanten, Yeşiltaş ve Arslan, 2015: 369). Bu kişiler soğuk davranan, sinik, pragmatik, ahlaki temelde düşünmeyen, uzun dönemli stratejik planlar yapan, yalan ve suistimale dayalı hareket eden bireylerdir. Makyavelist kişiler, kendi faydasını düşünerek hareket eder ve işini yaparken çok az motive olurlar (Rauthmann ve 
Kolar, 2012: 884-885). Bu kişiler, insanlardan ve toplumdan kaçan, empati eksikliği bulunan, anti-sosyal eğilimleri olan, güç ve para ile motive olan, etkili ve sonuç veren kuralları bulunan bireylerdir (Rauthmann, 2012: 345). Bu kişiler, hedef odaklı hareket eder ve başkalarını manipüle ederek onları kendi çıkarları için kullanırlar. Bu kişiler, diğer insanları sonuca ulaşmak için kullanılan bir araç olarak görürler. Makyavelist kişiler, güvensiz tutumlara sahip ve kendi duygularını düzenleyebilen bireylerdir. Makyavelizm kavramı kişilik bozukluklarıyla ilgilidir. Makyavelist kişiler, başkalarını ikna etmek ve sosyal ikilemleri çözmek konusunda başarılıdırlar. Bu kişilerin aynı anda hem kırılgan hem de başarılı yapısı bu konuyu bilimsel olarak çalışmaya layık hale getirmektedir (Lang, 2015: 28).

\section{B. Yaşamın Anlamı}

Pozitif psikoloji paradigması, kişilerin yaşamlarını neyin daha değerli hale getirdiğine yönelik teori ve çalışmalara dayanır. Yaşamın anlamı, yaşam doyumu, yaşam kalitesi ve mutluluk gibi kavramlar 2000'li yıllarda pozitif psikoloji paradigmasının biçimlenmesiyle birlikte öne çıkmıştır (Aktaş ve Şimşek, 2014; Şimşek ve Aktaş, 2014: 124). Yaşamın anlamı konusuna son y1llarda artan bir ilgi mevcuttur. Bu konu, geniş anlamda iyi oluş kavramının önemli bir bileşeni olarak düşünülebilir. Yaşamın anlamı kavramı, kişilerin yaşamdaki tüm hedefleri, misyonu ve amaçlarının seviyesiyle birlikte yaşamının önemi, anlamı ve hislerini ifade eden tüm boyutları içermektedir (Steger, Oishi ve Kashdan, 2009: 43). Yaşamın anlamı kavramı, iyi oluş ve sağlık konularına önemli katkılar sağlamaktadır. Güncel psikoloji literatüründe yaşamın anlamı kavramını tanımlayan iki merkezi unsur vardır. Bunlardan ilki kişilerin yaşamda yaptıklarını kavraması ve buna yönelik hisleri ile ilgili iken, diğeri ise yaşamdaki istekleri, temel hedefleri ve amacı ile ilişkilidir (Martela ve Steger, 2016).

Yaşamın anlamı, çeşitli şekillerde ele alınan çok yönlü yapısı olan bir kavramdır. Yaşamın anlamı denildiğinde yaşam değeri, amacı, önemli hedefleri ve maneviyat akla gelir (Yüksel, 2012: 81). Yaşamın anlamı, anlam arayışı (aranan anlam) ve anlamın varlığı (mevcut anlam) olmak üzere iki boyutlu olarak ele alınmaktadır. Anlamın varlı̆̆ı, kişilerin yaşamlarını önemli ve anlamlı olarak algılama seviyesi ile ilgili iken, anlam arayışı ise kişilerin yaşamlarının önem, anlam ve amacı temelinde bir anlayış meydana getirmek ve bunu geliştirmeye yönelik çabaları içerir. Anlamın varlığı bir sonucu içerirken, anlam arayışı bir süreci kapsamaktadır (Şahin vd., 2012: 829).

\section{Yaşam Doyumu}

Yaşam doyumu, kişinin bir bütün olarak kendi hayatına ilişkin bilişsel değerlendirmeleridir. Kişinin yaşamını bütün olarak değerlendirmesi, yaşamını çeşitli yönlerden kendi belirlediği standart ve kriterlere göre irdelemesidir (Proctor, Linley ve Maltby, 2009: 129). Yaşam doyumu, kişilerin mutluluk, moral ve günlük faaliyetler sonucunda sahip olduğu olumlu duyguların, olumsuz duygulardan üstün olması ile ilgilidir. Bu kavram kişilerin refahıyla ilgilidir. Yaşamından memnun olmayan kişiler anksiyete ve depresyona maruz kalabilir (Gürel ve Gürel, 2015: 41). Yaşam doyumu, kişilerin kendi yaşamlarının ne kadar iyi olduğuna ilişkin görüşlerini içerir. Yaşam doyumu, tümdengelimci bir bakış açısıyla, çoğunlukla 
kişilik gibi faktörlere bağlı olarak yaşamın bütün olarak değerlendirilmesidir (Şimşek ve Aktaş, 2014: 124). Yaşam doyumu, bireylerin beklentilerinin gerçek durumlar ile kıyaslanması sonucu ortaya çıkar. Bu kavram genel olarak bireyin yaşamının tümünü ve yaşamının çok çeşitli boyutlarını kapsar (Ural Uslan, 2016: 3356).

Yaşam doyumu, kişilerin kendi yaşamlarının kalitesini bir bütün halinde öznel olarak değerlendirmesidir. Bir kişinin beklentileriyle elde ettiklerini karş1laştırması sonucunda ortaya çıkar. Yaşam doyumu bireyin kendi yaşamına karşı genel bir tutumu ve memnuniyetini ifade eder (Çelik, 2016: 1141). Pozitif psikoloji ile ilgili araştırmalar, psikolojide önemli yeni bir yön olarak ortaya çıkmıştır. Psikolojinin geleneksel odağı olan depresyon ve anksiyete gibi negatif duyguların karşıtı olarak, bu konudaki birçok araştırma pozitif duygusal sonuçlara yönelmeye başlamıştır. Bu konulardaki araştırmalar git gide artmış ve genellikle mutluluk veya öznel iyi oluş kavramlarına odaklanmıştır (Pavot ve Diener, 2008: 137). Yaşam doyumu kavramı iş doyumu, gelir düzeyi, kişilik yapısı ve sosyal destek gibi değişkenlerle ilişkili olabilir. Yaşam doyumunu etkileyen önemli faktörlerden biri kişilerin hayatlarında önemli yeri olan iş yaşamıdır. Bu açıdan iş yaşamı ile yaşam doyumu ilişkili olabilir (Güner, Çiçek ve Can, 2014: 61).

\section{Değişkenler Arası İlişkiler ve Hipotezler}

Demirbaş Çelik (2016), üniversite öğrencilerinin yaşamda anlam seviyeleri ile yaşamın amacı düzeyleri arasındaki ilişkileri araştırmıştır. Demirbaş Çelik (2016) yaşamda anlamın varlığı ile yaşam amacı arasında pozitif yönlü bir ilişki belirlemiş iken, yaşamda anlam arayışı ile yaşam amacı arasında negatif yönlü bir ilişki olduğunu ifade etmiştir. Ali ve Chamorro-Premuzic (2010), makyavelist eğilim düzeyi ile yaşam doyumu arasında negatif yönlü anlamlı bir ilişki olduğunu ifade etmişlerdir. Akın ve Taş (2015), yaşamın anlamı ile yaşam doyumu, dışadönüklük ve sorumluluk arasında pozitif yönlü bir ilişki olabileceğini belirtmiştir. Akın ve Taş (2015), yaşamın anlamı ile korku, öfke, utangaçlık ve depresyon arasında negatif yönlü bir ilişki olabileceğini ifade etmiştir. Pan vd. (2008) üniversite öğrencileri üzerine gerçekleştirdikleri araştırmalarında yaşamın anlamı ile yaşam doyumu arasında pozitif yönlü anlamlı bir korelasyon olduğunu ve yaşamın anlamı düzeyinin yaşam doyumu üzerine pozitif anlamlı bir etkisi olduğunu saptamışlardır.

Y1kılmaz ve Demir Güdül (2015), üniversite öğrencileri üzerine uyguladığı araştırmalarında yaşam doyumu ile mevcut anlam arasında pozitif yönlü anlamlı bir ilişki olduğunu ve yaşam doyumu ile aranan anlam arasında negatif yönde anlamlı bir ilişki olduğunu ifade etmişlerdir. Yıkılmaz ve Demir Güdül (2015), mevcut anlam düzeyinin yaşam doyumu üzerine anlamlı olarak etki ettiğini ve aranan anlam seviyesinin yaşam doyumuna bir etkisi olmadığını belirtmişlerdir. Datu ve Mateo (2015) kolej öğrencileri üzerine uyguladığı araştırmalarında mevcut anlam ile yaşam doyumu arasında pozitif yönlü anlamlı bir korelasyon olduğunu ve mevcut anlam düzeyinin yaşam doyumu üzerine pozitif yönlü bir etkisi olduğunu saptamışlardır. Datu ve Mateo (2015), aranan anlam ile yaşam doyumu arasında anlamlı bir korelasyon olmadığını belirlemişlerdir. Eakman ve Eklund 
(2012) üniversite öğrencilerine gerçekleştirdikleri araştırmada yaşamın anlamı ölçeğinin alt boyutu olan mevcut anlam ile yaşam doyumu arasında pozitif yönlü anlamlı bir korelasyon olduğunu belirlemişlerdir. $\mathrm{Bu}$ kapsamda aşağıdaki hipotezler oluşturulmuştur:

\section{Hipotezler}

$\mathrm{H}_{1}$ :Makyavelist kişilik eğiliminin aranan anlam üzerine anlamlı bir etkisi vardır. $\mathrm{H}_{1 a}$ :Dürüst kişilik eğiliminin aranan anlam üzerine anlamlı bir etkisi vardır. $\mathrm{H}_{1 b}$ :Olumsuz kişilik eğiliminin aranan anlam üzerine anlamlı bir etkisi vardır. $\mathrm{H}_{1 c}$ :Olumlu kişilik eğiliminin aranan anlam üzerine anlamlı bir etkisi vardır. $\mathrm{H}_{2}$ : Makyavelist kişilik eğiliminin mevcut anlam üzerine anlamlı bir etkisi vardır. $\mathrm{H}_{2 \mathrm{a}}$ :Dürüst kişilik eğiliminin mevcut anlam üzerine anlamlı bir etkisi vardır. $\mathrm{H}_{2 \mathrm{~b}}$ :Olumsuz kişilik eğiliminin mevcut anlam üzerine anlamlı bir etkisi vardır. $\mathrm{H}_{2 c}$ :Olumlu kişilik eğiliminin mevcut anlam üzerine anlamlı bir etkisi vardır. $\mathrm{H}_{3}$ : Makyavelist kişilik eğiliminin yaşam doyumu üzerine anlamlı bir etkisi vardir.

$\mathrm{H}_{3 a}$ : Dürüst kişilik eğiliminin yaşam doyumu üzerine anlamlı bir etkisi vardır. $\mathrm{H}_{3 b}$ :Olumsuz kişilik eğiliminin yaşam doyumu üzerine anlamlı bir etkisi vardır. $\mathrm{H}_{3 c}$ :Olumlu kişilik eğiliminin yaşam doyumu üzerine anlamlı bir etkisi vardır. $\mathrm{H}_{4}$ : Yaşamın anlamı düzeyinin yaşam doyumu üzerine anlamlı bir etkisi vardır. $\mathrm{H}_{4 a}$ : Aranan anlam düzeyinin yaşam doyumu üzerine anlamlı bir etkisi vardır. $\mathrm{H}_{4 \mathrm{~b}}$ : Mevcut anlam düzeyinin yaşam doyumu üzerine anlamlı bir etkisi vardır.

\section{II.ARAŞTIRMA}

\section{A. Araştırmanın Amacı}

Araştırmanın amacı, üniversite öğrencilerinin makyavelist kişilik eğilimi algılarının yaşamın anlamı ve yaşam doyumları üzerine olan etkisini ele almaktır. Ayrıca öğrencilerin yaşamın anlamı düzeylerinin yaşam doyumları üzerine etkisi incelenmiştir.

\section{B. Örneklem ve Evren}

Araştırmanın örneklemi, bir devlet üniversitesinin uygulamalı bilimler yüksekokullarında öğrenim gören 365 öğrencidir. Bu kapsamda bir devlet üniversitesinin iki ayrı uygulamalı bilimler yüksekokulunda öğrenim gören 365 öğrenciden veriler elde edilmiştir. Araştırmanın evreni, bu devlet üniversitesinde okuyan tüm öğrencilerdir.

\section{Geri Dönüș Oranı ve Sınırlılıklar}

Araştırma kapsamında 380 adet anket dağıtılmış, bu anketlerden 365 tanesi tam ve eksiksiz olarak doldurulmuştur. Geri dönüş oranı \%96'dır. Sinırlılıklar yalnızca bir üniversitedeki öğrencilere araştırma yapılması ve bu üniversitede sadece uygulamalı bilimler yüksekokullarında öğrenim gören öğrencilerin araştırmaya dahil edilmesi olarak sıralanabilir.

\section{D. Ölçüm Araçları}

Araştırmada makyavelist kişilik eğilimini ölçmek için Christie ve Geis (1970) tarafından geliştirilen 20 soruluk Mach IV ölçeği kullanılmıştır. Bu ölçek ülkemizde daha önce birçok araştırmada kullanılmıştır. Ölçekte 10 olumlu ve 10 olumsuz soru vardır. Ölçek Engeler ve Yargıç (2004) tarafindan Türkçe’ye 
uyarlanmıştır. Yaşamın anlamı ölçeği Steger vd. (2006) tarafından geliştirilen 10 soruluk bir formdur. Yaşamın anlamı ölçeği geçerlik ve güvenirlik çalışması Akın ve Taş (2011) tarafından yapılmıştır. Yaşamın anlamı ölçeği toplam 10 soru ve 2 alt boyuttan oluşan bir formdur. İlk alt boyut olan mevcut anlam soru 1, 4, 5, 6 ve 9'u içermektedir. Diğer boyut olan aranan anlam ise soru 2, 3, 7, 8 ve 10'u kapsamaktadır. Yaşamın anlamı ölçeğinde soru 9 ters puanlanmaktadır (Akın ve Taş, 2015: 31). Çalışmada Diener vd. (1985) tarafından geliştirilen 5 soruluk yaşam doyumu ölçeği kullanılmıştır. Ölçeği Köker (1991) Türkçe’ye uyarlamıştır. Araştırmada kullanılan makyavelist kişilik eğilimi ölçeği (Mach IV), yaşamın anlamı ölçeği ve yaşam doyumu ölçeği için "Kesinlikle katılmıyorum=1", "Katılmiyorum=2", "Kararsızım=3", "Katılıyorum=4" ve "Kesinlikle Katılıyorum=5" olmak üzere beşli Likert puanlama kullanılmıştır. Ayrıca sosyodemografik özelliklerin belirlenmesine ilişkin olarak cinsiyet, sınıf düzeyi, baba eğitim durumu, anne eğitim durumu, kardeş sayısı ile ilgili sorular yöneltilmiştir.

\section{E.Araştırma Modeli}

Araştırma modeli makyavelist kişilik eğilimi, yaşamın anlamı ve yaşam doyumu olmak üzere üç temel değişken üzerine kurulmuştur. Öncelikle makyavelist kişilik eğiliminin yaşamın anlamı üzerine etkisi incelenmiştir. Bu kapsamda iki çoklu regresyon modeli test edilmiştir $\left(\mathrm{H}_{1}\right.$ ve $\left.\mathrm{H}_{2}\right)$. Makyavelist kişilik eğiliminin yaşamın anlamı alt boyutlarından aranan anlam üzerine etkisine ilişkin bir çoklu regresyon modeli sınanmıştır. Makyavelist kişilik eğiliminin yaşamın anlamı alt boyutlarından mevcut anlam üzerine etkisine yönelik olarak bir çoklu regresyon modeli test edilmiştir. Burada makyavelist kişilik eğilimi alt boyutları bağımsız değişken olarak, yaşamın anlamı alt boyutları ayrı ayrı bağımlı değişken olarak ele alınmıştır. Araştırma modeline göre ikinci olarak makyavelist kişilik eğiliminin yaşam doyumu üzerine etkisi incelenmiştir. Bu kapsamda bir çoklu regresyon modeli sınanmıştır $\left(\mathrm{H}_{3}\right)$. Burada makyavelist kişilik eğilimi alt boyutları bağımsız değişken olarak, yaşam doyumu bağımlı değişken olarak ele alınmıştır. Modele göre son olarak yaşamın anlamı düzeyinin yaşam doyumu üzerine etkisi ele alınmıştır. Bu kapsamda bir çoklu regresyon modeli test edilmiştir $\left(\mathrm{H}_{4}\right)$. Burada yaşamın anlamı alt boyutları bağımsız değişken olarak, yaşam doyumu bağımlı değişken olarak ele alınmıştır. Araştırma modeli kapsamında toplam 4 ayrı çoklu regresyon modeli test edilmiştir. 
Şekil 1. Araştırma Modeli

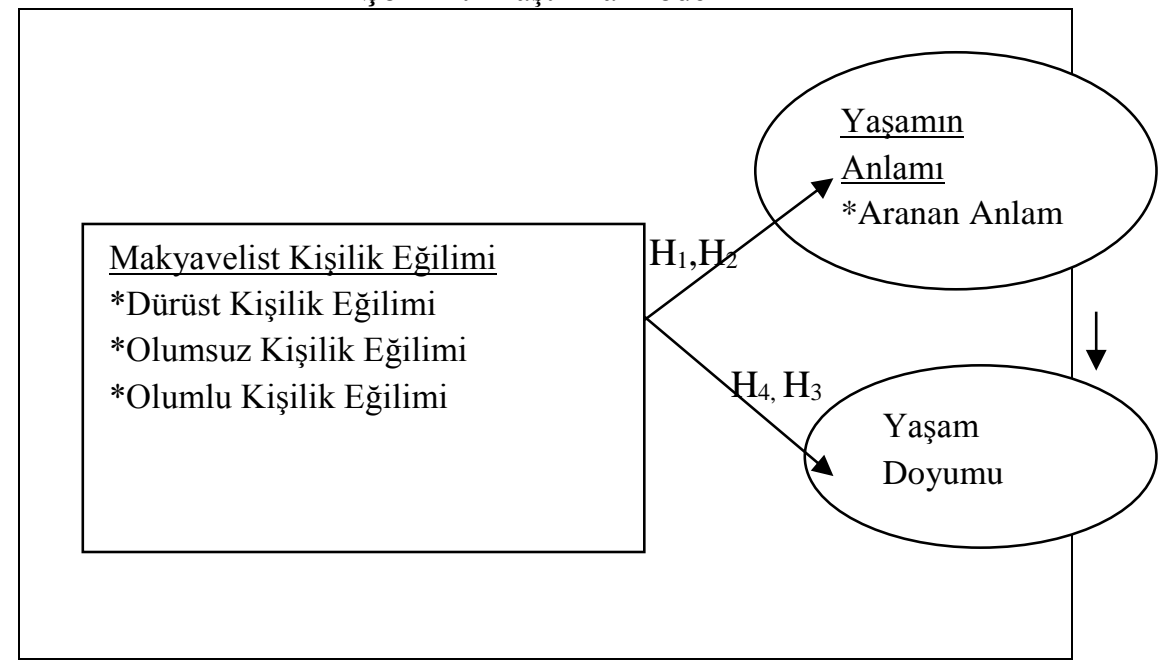

\section{BULGULAR}

Çalışmada veri analizi SPSS 21 istatistik paket programı kullanılarak yapılmıştır. $\mathrm{Bu}$ kapsamda frekans analizi, faktör analizi, güvenirlik testi, çoklu regresyon testi ve korelasyon analizi uygulanmıştır. Araştırmada öncelikle üniversite öğrencilerinin sosyo-demografik özelliklerine ilişkin frekans dağılımı yapılmıştır. Daha sonra makyavelist kişilik eğilimi, yaşamın anlamı ve yaşam doyumu ölçeklerine faktör analizi ve güvenirlik testleri uygulanmıştır. Makyavelist kişilik eğilimi ölçeğine faktör analizi uygulanması sonucu üç alt boyut ortaya çıkmıştır. Bu boyutlar sırasıyla "dürüst kişilik eğilimi”, "olumsuz kişilik eğilimi”" ve "olumlu kişilik eğilimi" olarak isimlendirilmiştir. Yaşamın anlamı ölçeğine faktör analizi uygulanması neticesinde iki alt boyut bulunmuştur. Bu boyutlar "aranan anlam" ve "mevcut anlam" olarak isimlendirilmiştir. Yaşam doyumu ölçeğine faktör analizi uygulaması yapılmış ve tek boyut ortaya çıkmıştır. Bu boyut yaşam doyumu olarak adlandırılmıştır. Bunun sonrasında araştırmada kullanılan değişkenlere güvenirlik testleri uygulanmış ve Cronbach's Alpha değerleri incelenmiştir. Cronbach's Alpha değerlerinin genel olarak kabul edilebilir düzeyde olduğu söylenebilir.

Makyavelist kişilik eğiliminin yaşamın anlamı düzeyi üzerine etkisine yönelik olarak iki ayrı çoklu regresyon modeli sınanmıştır. Bu kapsamda makyavelist kişilik eğiliminin aranan anlam üzerine etkisine yönelik bir çoklu regresyon modeli denenmiştir. Makyavelist kişilik eğiliminin mevcut anlam üzerine etkisine ilişkin olarak da bir çoklu regresyon modeli denenmiştir. Daha sonra makyavelist kişilik eğiliminin yaşam doyumu üzerine etkisine ilişkin olarak bir çoklu regresyon modeli sınanmıştır. Yaşamın anlamı düzeyinin yaşam doyumu üzerine etkisine ilişkin olarak bir çoklu regresyon modeli test edilmiştir. Araştırmada toplam dört ayrı çoklu regresyon modeli denenmiştir. 


\section{A. Frekans Analizi}

Araştırmaya katılan öğrencilerin sosyo-demografik özelliklerinin dağılımına ilişkin frekans dağılımı Tablo 1'de gösterilmiştir. Bu kapsamda öğrencilerin cinsiyet, sınıf düzeyi, baba eğitim durumu, anne eğitim durumu ve kardeş sayısına yönelik frekans dağılımları aşağıda ifade edilmiştir.

Tablo 1. Sosyo-demografik Özelliklere İlişkin Frekans Dağılımı

\begin{tabular}{|c|c|c|c|}
\hline Değişkenler & Gruplar & Frekans & Yüzde \\
\hline \multirow[t]{2}{*}{ Cinsiyet } & Erkek & 181 & 49,6 \\
\hline & Kadın & 184 & 50,4 \\
\hline \multirow[t]{4}{*}{ Sınıf Düzeyi } & $1 . s i n i f$ & 128 & 35,1 \\
\hline & 2.sinif & 134 & 36,7 \\
\hline & 3.sinif & 63 & 17,3 \\
\hline & $4 . \sin 1 f$ & 40 & 11,0 \\
\hline \multirow[t]{6}{*}{ Baba Eğitim Durumu } & Okuryazar Değil & 4 & 1,1 \\
\hline & İlk-Orta & 232 & 63,6 \\
\hline & Lise & 90 & 24,7 \\
\hline & MYO & 13 & 3,6 \\
\hline & Üniversite & 22 & 6,0 \\
\hline & Y.Lisans & 4 & 1,1 \\
\hline \multirow[t]{6}{*}{ Anne Eğitim Durumu } & Okuryazar Değil & 20 & 5,5 \\
\hline & İlk-Orta & 273 & 74,8 \\
\hline & Lise & 57 & 15,6 \\
\hline & MYO & 4 & 1,1 \\
\hline & Üniversite & 8 & 2,2 \\
\hline & Y.Lisans & 3 & 0,8 \\
\hline \multirow[t]{4}{*}{ Kardeş Sayısı } & 1 kardeş & 26 & 7,1 \\
\hline & 2 kardeş & 158 & 43,3 \\
\hline & 3 kardeş & 106 & 29,0 \\
\hline & 4 ve üzeri kardeş & 75 & 20,5 \\
\hline
\end{tabular}

\section{B. Faktör Analizi ve Güvenirlik Testi}

Makyavelist kişilik eğilimi ölçeğine faktör analizi ile güvenirlik testi uygulanmış ve sonuçlar Tablo 2'de ifade edilmiştir. 350 ve üzerindeki gözlem sayılarında faktör ağırlığı 0,30 ve üzerinde olması gerekir (Kalaycı, 2010: 330; Alpar, 2011: 283). Araştırma örneklemi 365 kişiden oluştuğu için faktör ağırlıklarının 0,30 ve üzerinde olmasına dikkat gösterilmiştir.

Tablo 2. Makyavelist Kişilik Eğilimi Ölçeği Faktör Analizi ve Güvenirlik Testi Sonuçları

\begin{tabular}{|c|c|c|c|c|c|}
\hline & Sorular & $\begin{array}{l}\text { Faktör } \\
\text { Ağırlıkları }\end{array}$ & $\begin{array}{l}\text { Faktör } \\
\text { Açılayıcıllı̆̆ı(\%) }\end{array}$ & $\begin{array}{l}\text { Başlangıç } \\
\text { Özdeğerleri }\end{array}$ & $\begin{array}{l}\text { Cronbach's } \\
\text { Alpha }\end{array}$ \\
\hline \multirow{7}{*}{$\begin{array}{l}\text { Dürüst } \\
\text { Kişilik } \\
\text { Eğilimi }\end{array}$} & M10 & 0,767 & \multirow[t]{6}{*}{12,664} & \multirow{6}{*}{2,861} & \multirow{6}{*}{0,667} \\
\hline & M5 & 0,756 & & & \\
\hline & M2 & 0,613 & & & \\
\hline & M15 & 0,531 & & & \\
\hline & M11 & 0,465 & & & \\
\hline & M8 & 0,363 & & & \\
\hline & M19 & 0,591 & 11,392 & 2,117 & \\
\hline
\end{tabular}




\begin{tabular}{|c|c|c|c|c|c|}
\hline \multirow{8}{*}{$\begin{array}{l}\text { Olumsuz } \\
\text { Kişilik } \\
\text { Eğilimi }\end{array}$} & M7 & 0,536 & & & \multirow[t]{8}{*}{0,588} \\
\hline & M6 & 0,536 & & & \\
\hline & M12 & 0,516 & & & \\
\hline & M4 & 0,500 & & & \\
\hline & M1 & 0,468 & & & \\
\hline & M18 & 0,415 & & & \\
\hline & M3 & 0,340 & & & \\
\hline & M16 & 0,308 & & & \\
\hline \multirow{5}{*}{$\begin{array}{l}\text { Olumlu } \\
\text { Kişilik } \\
\text { Eğilimi }\end{array}$} & M14 & 0,693 & \multirow{5}{*}{10,117} & \multirow{5}{*}{1,857} & \multirow{5}{*}{0,566} \\
\hline & M17 & 0,669 & & & \\
\hline & M20 & 0,637 & & & \\
\hline & M13 & 0,496 & & & \\
\hline & M9 & 0,395 & & & \\
\hline
\end{tabular}

Tablo 2'de görüldüğü gibi KMO değeri 0,732 ve Bartlett's testi sonucu bulunan $p$ değeri 0,000 olduğu için veri setinin faktör analizine uygun olduğu söylenebilir. Makyavelist kişilik eğilimi ölçeğine faktör analizi uygulanmış ve üç alt boyut ortaya çıkmıştır. Bu boyutlar "Dürüst Kişilik Eğilimi”, "Olumsuz Kişilik Eğilimi”" ve "Olumlu Kişilik Eğilimi”" olarak adlandırılmıştır. "Dürüst Kişilik Eğilimi”" boyutu toplam varyansın \%12,664'ünü açıklamaktadır. "Olumsuz Kişilik Eğilimi” boyutunun toplam varyansın \%11,392'sini açıkladığı gözlenmiştir. “Olumlu Kişilik Eğilimi” boyutu toplam varyansın \%10,117'sini açıklamaktadır. Makyavelist kişilik eğiliminin üç alt boyutu toplam varyansın \%34,173'ünü açıklamaktadır. Başlangıç özdeğerlerinin faktör 1 için 2,861, faktör 2 için 2,117 ve faktör 3 için 1,857 olduğu gözlenmiştir. Güvenirlik testi sonucu bulunan Cronbach's Alpha değerlerinin faktör 1 için 0,667 , faktör 2 için 0,588 ve faktör 3 için 0,566 olduğu gözlenmiştir. Cronbach's Alpha değerlerinin genel olarak 0,50'nin üzerinde olduğu görülmektedir.

Yaşamın anlamı ölçeğine faktör analizi ile güvenirlik testi uygulanmış ve bulunan sonuçlar Tablo 3'te verilmiştir. Yaşamın anlamı ölçeğine faktör analizi uygulanırken soru 9 analiz dışı bırakılmıştır.

Tablo 3. Yaşamın Anlamı Ölçeği Faktör Analizi ve Güvenirlik Testi Sonuçları

\begin{tabular}{|c|c|c|c|c|c|}
\hline & Sorular & $\begin{array}{l}\text { Faktör } \\
\text { Ağırlıkları }\end{array}$ & $\begin{array}{l}\text { Faktör } \\
\text { Açıklayıcılığı(\%) }\end{array}$ & $\begin{array}{l}\text { Başlangıç } \\
\text { Özdeğerleri }\end{array}$ & $\begin{array}{l}\text { Cronbach's } \\
\text { Alpha }\end{array}$ \\
\hline \multirow[t]{5}{*}{ Aranan Anlam } & YA3 & 0,807 & \multirow[t]{5}{*}{31,905} & \multirow[t]{5}{*}{3,317} & \multirow[t]{5}{*}{0,809} \\
\hline & YA8 & 0,768 & & & \\
\hline & YA10 & 0,741 & & & \\
\hline & YA7 & 0,725 & & & \\
\hline & YA2 & 0,688 & & & \\
\hline \multirow[t]{4}{*}{ Mevcut Anlam } & YA4 & 0,813 & \multirow[t]{4}{*}{26,740} & \multirow[t]{4}{*}{1,962} & \multirow[t]{4}{*}{0,762} \\
\hline & YA5 & 0,781 & & & \\
\hline & YA6 & 0,773 & & & \\
\hline & YA1 & 0,659 & & & \\
\hline
\end{tabular}

KMO Değeri: 0,807; Bartlett's Testi Sonucu: 0,000; Açıklanan Toplam Varyans: 58,646

Tablo 3'te görüldüğü üzere KMO değeri 0,807 ve Bartlett's testi sonucu bulunan $p$ değeri 0,000 olduğu için veri seti faktör analizine uygundur. Yaşamın 
anlamı ölçeğine faktör analizi uygulanması sonucu iki alt boyut ortaya çıkmıştır. Bu boyutlar ölçeğin orijinalindeki gibi "Aranan Anlam" ve "Mevcut Anlam” olarak adlandırılmıştır. "Aranan Anlam" boyutu toplam varyansın \%31,905'ini açıklamaktadır. "Mevcut Anlam" boyutu toplam varyansın \%26,740'ını açıklamaktadır. Yaşamın anlamı ölçeğinin iki alt boyutu toplam varyansın \%58,646'sını açıklamaktadır. Başlangıç özdeğerlerinin faktör 1 için 3,317, faktör 2 için 1,962 olduğu gözlenmiştir. Cronbach's Alpha değerlerinin faktör 1 için 0,809 ve faktör 2 için 0,762 olduğu gözlenmiştir. Yaşamın anlamı ölçeği alt boyutlarının Cronbach's Alpha değerlerinin uygun düzeyde olduğu görülmektedir.

Yaşam doyumu ölçeğine faktör analizi ile güvenirlik testi uygulanmış ve bulunan sonuçlar aşağıda Tablo 4'te ifade edilmiştir.

Tablo 4. Yaşam Doyumu Ölçeği Faktör Analizi ve Güvenirlik Testi Sonuçları

\begin{tabular}{|c|c|c|c|c|c|}
\hline & Sorular & $\begin{array}{l}\text { Faktör } \\
\text { Ağırlıkları }\end{array}$ & $\begin{array}{l}\text { Faktör } \\
\text { Açılayıc1lı̆̆l}(\%)\end{array}$ & $\begin{array}{l}\text { Başlangıç } \\
\text { Özdeğerleri }\end{array}$ & $\begin{array}{l}\text { Cronbach's } \\
\text { Alpha }\end{array}$ \\
\hline \multirow{5}{*}{$\begin{array}{l}\text { Yaşam } \\
\text { Doyumu }\end{array}$} & $\mathrm{yd} 1$ & 0,789 & \multirow[t]{5}{*}{56,332} & \multirow[t]{5}{*}{2,817} & \multirow{5}{*}{0,801} \\
\hline & $\mathrm{yd} 4$ & 0,785 & & & \\
\hline & $\mathrm{yd} 3$ & 0,785 & & & \\
\hline & $\mathrm{yd} 2$ & 0,721 & & & \\
\hline & yd5 & 0,665 & & & \\
\hline
\end{tabular}

Tablo 4'te görüldüğü gibi KMO değeri 0,821 ve Bartlett's testi sonucu bulunan $p$ değeri 0,000 olduğundan veri seti faktör analizine uygundur. Yaşam doyumu ölçeğine faktör analizi uygulanması sonucu tek boyut ortaya çıkmış ve bu boyut ölçeğin orijinalindeki gibi yaşam doyumu olarak isimlendirilmiştir. Yaşam doyumu boyutu toplam varyansın \%56,332'sini açıklamaktadır. Yaşam doyumu boyutu için başlangıç özdeğerinin 2,817 olduğu gözlenmiş̧tir. Yaşam doyumu boyutu için Cronbach's Alpha değerinin 0,801 olduğu gözlenmiştir. Bu değerin uygun düzeyde olduğu görülmektedir.

\section{C. Çoklu Regresyon Testleri}

Çoklu regresyon testlerine geçmeden önce çoklu bağıntının olup olmadığı araştırılmıştır. Belirtildiği gibi makyavelist kişilik eğilimi alt boyutları bağımsız değişken olarak ele alınmıştır. Bu kapsamda bağımsız değişkenler (dürüst kişilik eğilimi, olumsuz kişilik eğilimi ve olumlu kişilik eğilimi) arasındaki korelasyon katsayıları, VIF değerleri, tolerans istatistik değerleri ve koşul indeksleri (condition index) incelenmiştir.

Çoklu bağıntı sorununun olmaması için bağımsız değişkenler arası korelasyonlar 0,7 'nin altında olmalı, tolerans istatistiği 0,1 'in üzerinde olmalı, VIF değeri 10'un altında olmalı ve koşul indeksi değeri 30'un altında olmalıdır (Sipahi, Yurtkoru ve Çinko, 2010; Çokluk, Şekercioğlu ve Büyüköztürk, 2012; Saruhan ve Özdemirci, 2011). Bağımsız değişkenler (dürüst kişilik eğilimi, olumsuz kişilik eğilimi ve olumlu kişilik eğilimi) arasındaki korelasyon katsayılarının 0,7'nin oldukça altında olduğu, en yüksek VIF değerinin 1,067 olduğu ve bu değerin sınır değer olan 10'un oldukça altında olduğu, en düşük tolerans istatistiğinin 0,937 olduğu ve bu değer sınır değer olan 0,1 'in oldukça üzerinde olduğu, en yüksek 
koşul indeksi değerinin 16,313 olduğu ve bunun sınır değer olan 30'un oldukça altında olduğu gözlenmiştir. Bu kapsamda bağımsız değişkenler için çoklu bağıntı sorunu olmadığı söylenebilir.

Makyavelist kişilik eğiliminin yaşamın anlamı alt boyutları üzerine etkisi iki çoklu regresyon modeli ile sınanmıştır. Öncelikle makyavelist kişilik eğiliminin aranan anlam üzerine etkisine ilişkin bir çoklu regresyon modeli test edilmiş ve sonuçlar aşağıda Tablo 5'te verilmiştir. Bu kapsamda makyavelist kişilik eğilimi alt boyutları bağımsız değişken iken, aranan anlam boyutu bağımlı değişken olarak değerlendirilmiştir.

Tablo 5.Makyavelist Kişilik Eğiliminin Aranan Anlam Üzerine Etkisine İlişkin Çoklu Regresyon Testi Sonuçları

\begin{tabular}{|c|c|c|c|c|c|}
\hline & \multicolumn{2}{|c|}{$\begin{array}{l}\text { Standardize Edilmemiş } \\
\text { Katsayılar }\end{array}$} & \multirow{2}{*}{$\begin{array}{c}\text { Standardize } \\
\text { Edilmiş } \\
\text { Katsayilar } \\
\text { Beta } \\
\end{array}$} & \multirow[t]{2}{*}{$\mathrm{t}$} & \multirow[t]{2}{*}{ Sig. } \\
\hline & B & Std. Hata & & & \\
\hline (Constant) & 1,773 & 0,310 & & 5,728 & 0,000 \\
\hline Dürüst Kişilik Eğilimi & 0,268 & 0,059 & $\mathbf{0 , 2 3 3}$ & 4,518 & $\mathbf{0 , 0 0 0}$ \\
\hline Olumsuz Kişilik Eğilimi & 0,205 & 0,073 & 0,146 & 2,824 & 0,005 \\
\hline Olumlu Kișilik Eğilimi & 0,030 & 0,059 & 0,025 & 0,502 & 0,616 \\
\hline
\end{tabular}

Tablo 5'te görüldüğü üzere $\mathrm{p}<0,05$ olduğundan $\mathrm{H}_{1 \mathrm{a}}$ ve $\mathrm{H}_{1 \mathrm{~b}}$ desteklenmiştir. Ayrıca $\mathrm{p}>0,05$ olduğundan $\mathrm{H}_{1 \mathrm{c}}$ reddedilmiştir. Dürüst kişilik eğiliminin aranan anlam üzerine pozitif yönlü anlamlı bir etkisi $(\beta=0,233)$ olduğu gözlenmiştir $(\mathrm{p}<0,05)$. Öğrencilerin dürüst kişilik eğilimi algıları arttıkça aranan anlam düzeyleri de artmaktadır. Dürüst kişilik eğilimine sahip olmak aranan anlam seviyesini arttırmaktadır. Olumsuz kişilik eğiliminin aranan anlam düzeyi üzerine pozitif yönlü anlamlı bir etkisi $(\beta=0,146)$ olduğu gözlenmiştir $(p<0,05)$. Öğrencilerin olumsuz kişilik eğilimi algıları arttıkça aranan anlam düzeyleri de artmaktadır. Kişilerin olumsuz kişilik eğilimleri aranan anlam düzeylerini arttırmaktadır. Dürüst kişilik eğiliminin aranan anlam üzerine etkisi $(\beta=0,233)$, olumsuz kişilik eğiliminin etkisinden $(\beta=0,146)$ fazladır. Dürüst kişilik eğilimi aranan anlam düzeyini daha fazla arttırmaktadır. Ayrıca olumlu kişilik eğiliminin aranan anlam üzerine anlamlı bir etkisi yoktur $(\mathrm{p}>0,05)$.

Makyavelist kişilik eğiliminin mevcut anlam üzerine etkisine yönelik olarak bir çoklu regresyon modeli sınanmış ve sonuçlar aşağıda Tablo 6'da verilmiştir. Bu kapsamda makyavelist kişilik eğilimi alt boyutları bağımsız değişken olarak, mevcut anlam boyutu bağımlı değişken olarak ele alınmıştır. 
Tablo 6. Makyavelist Kişilik Eğiliminin Mevcut Anlam Üzerine Etkisine Yönelik Çoklu Regresyon Testi Sonuçları

\begin{tabular}{|c|c|c|c|c|c|}
\hline & \multicolumn{2}{|c|}{$\begin{array}{l}\text { Standardize Edilmemiş } \\
\text { Katsayılar }\end{array}$} & \multirow{2}{*}{$\begin{array}{c}\text { Standardize } \\
\text { Edilmiş } \\
\text { Katsayılar } \\
\\
\text { Beta } \\
\end{array}$} & \multirow[t]{2}{*}{$\mathrm{t}$} & \multirow[t]{2}{*}{ Sig. } \\
\hline & $\mathrm{B}$ & Std. Hata & & & \\
\hline (Sabit) & 2,049 & 0,302 & & 6,793 & 0,000 \\
\hline Dürüst Kişilik Eğilimi & 0,334 & 0,058 & 0,297 & 5,793 & 0,000 \\
\hline Olumsuz Kişilik Eğilimi & $-0,094$ & 0,071 & $-0,068$ & $-1,324$ & 0,186 \\
\hline Olumlu Kişilik Eğilimi & 0,168 & 0,057 & 0,146 & 2,922 & 0,004 \\
\hline $\begin{array}{l}\text { Bağımlı Değişken: Mevcı } \\
\text { R: 0,324; } \mathrm{R}^{2}: 0,105 ; \text { Düze }\end{array}$ & 107. & 13 & $93 ; \mathrm{p}: 0$, & & \\
\hline
\end{tabular}

Tablo 6'da görüldüğü gibi $\mathrm{p}<0,05$ olduğundan $\mathrm{H}_{2 \mathrm{a}}$ ve $\mathrm{H}_{2 \mathrm{c}}$ desteklenmiştir. Ayrıca $\mathrm{p}>0,05$ olduğundan $\mathrm{H}_{2 b}$ reddedilmiştir. Dürüst kişilik eğiliminin mevcut anlam üzerine pozitif yönlü anlamlı bir etkisi $(\beta=0,297)$ olduğu gözlenmiştir $(p<0,05)$. Öğrencilerin dürüst kişilik eğilimi algıları arttıkça mevcut anlam düzeyleri de artmaktadır. Öğrencilerin dürüst kişilik eğilimine sahip olması mevcut anlam düzeylerini yükseltmektedir. Olumlu kişilik eğiliminin mevcut anlam üzerine pozitif yönlü anlamlı bir etkisi $(\beta=0,146)$ olduğu gözlenmiştir $(p<0,05)$. Öğrencilerin olumlu kişilik eğilimi algıları arttıkça mevcut anlam düzeyleri de artmaktadır. Öğrencilerin olumlu kişilik algısına sahip olması mevcut anlam seviyelerini yükseltmektedir. Dürüst kişilik eğiliminin mevcut anlam üzerine etkisi $(\beta=0,297)$, olumlu kişilik eğiliminin etkisinden $(\beta=0,146)$ yüksektir. Dürüst kişilik eğilimi mevcut anlam seviyesini daha fazla arttırmaktadır. Olumsuz kişilik eğiliminin mevcut anlam üzerine anlamlı bir etkisi yoktur $(\mathrm{p}>0,05)$.

Makyavelist kişilik eğiliminin yaşam doyumu üzerine etkisine ilişkin bir çoklu regresyon modeli denenmiş ve sonuçlar aşağıda Tablo 7'de gösterilmiştir. Makyavelist kişilik eğilimi alt boyutları bağımsız değişken iken, yaşam doyumu bağımlı değişken olarak değerlendirilmiştir.

Tablo 7. Makyavelist Kişilik Eğiliminin Yaşam Doyumu Üzerine Etkisine İlişkin Çoklu Regresyon Testi Sonuçları

\begin{tabular}{|c|c|c|c|c|c|}
\hline & \multicolumn{2}{|c|}{$\begin{array}{l}\text { Standardize Edilmemiş } \\
\text { Katsayılar }\end{array}$} & \multirow{2}{*}{$\begin{array}{l}\text { Standardize } \\
\text { Edilmiş } \\
\text { Katsayılar } \\
\\
\text { Beta }\end{array}$} & \multirow[t]{2}{*}{$\mathrm{t}$} & \multirow[t]{2}{*}{ Sig. } \\
\hline & $\mathrm{B}$ & Std. Hata & & & \\
\hline (Sabit) & 1,471 & 0,311 & & 4,723 & 0,000 \\
\hline Dürüst Kişilik Eğilimi & 0,224 & 0,060 & $\mathbf{0 , 1 8 9}$ & 3,765 & 0,000 \\
\hline Olumsuz Kişilik Eğilimi & $-0,116$ & 0,073 & $-0,080$ & $-1,591$ & 0,112 \\
\hline
\end{tabular}




\begin{tabular}{|l|r|r|r|r|r|}
\hline Olumlu Kişilik Eğilimi & 0,396 & 0,059 & $\mathbf{0 , 3 2 7}$ & 6,667 & $\mathbf{0 , 0 0 0}$ \\
\hline Bağımlı Değişken: Yaşam Doyumu \\
R: 0,374; R $^{2}: 0,140 ;$ Düzeltilmiş R ${ }^{2}: 0,133$; Std. Hata: 0,83980; F: 19,586; p:0,000 \\
\hline
\end{tabular}

Tablo 7'ye bakıldığında $\mathrm{p}<0,05$ olduğu için $\mathrm{H}_{3 \mathrm{a}}$ ve $\mathrm{H}_{3 c}$ desteklenmiştir. Ayrıca $\mathrm{p}>0,05$ olduğu için $\mathrm{H}_{3 \mathrm{~b}}$ reddedilmiştir. Dürüst kişilik eğiliminin yaşam doyumu üzerine pozitif yönlü anlamlı bir etkisi $(\beta=0,189)$ vardır $(p<0,05)$. Öğrencilerin dürüst kişilik eğilimi algıları arttıkça yaşam doyumları da artmaktadır. Dürüst kişilik eğilimine sahip olmak yaşam doyumunu arttırmaktadır. Olumlu kişilik eğiliminin yaşam doyumu üzerine pozitif yönlü anlamlı bir etkisi $(\beta=0,327)$ olduğu gözlenmiştir $(p<0,05)$. Öğrencilerin olumlu kişilik eğilimi algıları arttıkça yaşam doyumları da artmaktadır. Olumlu kişilik eğilimi sahibi olmak yaşam doyumunu yükseltmektedir. Olumlu kişilik eğiliminin yaşam doyumu üzerine olan etkisi $(\beta=0,327)$, dürüst kişilik eğiliminin etkisinden $(\beta=0,189)$ yüksektir. $\mathrm{Bu}$ kapsamda olumlu kişilik eğiliminin yaşam doyumunu daha çok arttırdığ söylenebilir. Olumsuz kişilik eğiliminin yaşam doyumu üzerine anlamlı bir etkisinin olmadığı gözlenmiştir ( $\mathrm{p}>0,05)$.

Çoklu regresyon testine geçmeden önce bağımsız değişken olarak ele alınan yaşamın anlamı alt boyutlarına ilişkin olarak çoklu bağıntı araştırılmıştır. Bağımsız değişkenler (Aranan anlam ve mevcut anlam) arasındaki korelasyon katsayılarının 0,7'nin oldukça altında olduğu, en yüksek VIF değerinin 1,066 olduğu ve bunun sınır değer olan 10'un oldukça altında olduğu, tolerans istatistiğinin en düşük değerinin 0,938 olduğu ve bunun sınır değer olan 0,1 'in oldukça üzerinde olduğu ve son olarak koşul indeksinin en yüksek değerinin 10,781 olduğu ve bunun 30'un oldukça altında olduğu gözlenmiştir. Bu nedenlerden dolay1 çoklu bağıntı sorunu olmadığı söylenebilir.

Yaşamın anlamı düzeyinin yaşam doyumu üzerine etkisine dönük olarak bir çoklu regresyon modeli sınanmıştır. Bulunan sonuçlar aşağıda Tablo 8'de verilmiştir.

Tablo 8. Yaşamın Anlamı Düzeyinin Yaşam Doyumu Üzerine Etkisine Yönelik Çoklu Regresyon Testi Sonuçları

\begin{tabular}{|c|c|c|c|c|c|}
\hline & \multicolumn{2}{|c|}{$\begin{array}{c}\text { Standardize Edilmemiş } \\
\text { Katsayılar }\end{array}$} & \multirow{2}{*}{$\begin{array}{c}\text { Standardize } \\
\text { Edilmiş } \\
\text { Katsaylar } \\
\\
\text { Beta } \\
\end{array}$} & \multirow[t]{2}{*}{$\mathrm{t}$} & \multirow[t]{2}{*}{ Sig. } \\
\hline & B & Std. Hata & & & \\
\hline (Sabit) & 0,912 & 0,209 & & 4,363 & 0,000 \\
\hline Aranan Anlam & 0,095 & 0,048 & 0,092 & 1,972 & $\overline{0,049}$ \\
\hline Mevcut Anlam & 0,507 & 0,049 & 0,482 & 10,332 & 0,000 \\
\hline
\end{tabular}


Tablo 8'de görüldüğü üzere, $\mathrm{p}<0,05$ olduğundan $\mathrm{H}_{4 a}$ ve $\mathrm{H}_{4 b}$ desteklenmiştir $(\mathrm{p}<0,05)$. Aranan anlam düzeyinin yaşam doyumu üzerine pozitif yönlü anlamlı bir etkisi $(\beta=0,092)$ olduğu gözlenmiştir $(p<0,05)$. Öğrencilerin aranan anlam algıları arttıkça yaşam doyumları da artmaktadır. Aranan anlam düzeyinin yaşam doyumunu yükselttiği söylenebilir. Mevcut anlam düzeyinin yaşam doyumu üzerine pozitif yönlü anlamlı bir etkisi $(\beta=0,482)$ olduğu gözlenmiştir $(p<0,05)$. Öğrencilerin mevcut anlam algıları arttıkça yaşam doyumları da artmaktadır. Mevcut anlam seviyesinin yaşam doyumunu arttırdığı söylenebilir. Mevcut anlam düzeyinin yaşam doyumu üzerine olan etkisi $(\beta=0,482)$, aranan anlam düzeyinin etkisine $(\beta=0,092)$ göre oldukça yüksektir. Başka bir ifadeyle mevcut anlam düzeyinin yaşam doyumunu daha çok arttırdığı söylenebilir.

\section{Korelasyon Testleri}

Araştırmada kullanılan değiş̧kenler arası korelasyonlar, ortalamalar ve standart sapmalar aşağıda Tablo 9'da verilmiştir.

Tablo 9. Korelasyon Analizleri, Ortalamalar ve Standart Sapmalar

\begin{tabular}{|c|c|c|c|c|c|c|c|c|}
\hline & $\begin{array}{l}\text { Ortal } \\
\text { ama }\end{array}$ & $\begin{array}{c}\text { Std. } \\
\text { Sapm } \\
\text { a }\end{array}$ & 1 & 2 & 3 & 4 & 5 & 6 \\
\hline \multirow{2}{*}{$\begin{array}{l}\text { Dürüst } \\
\text { Kişilik } \\
\text { Eğilimi }\end{array}$} & \multirow[t]{2}{*}{3,63} & \multirow[t]{2}{*}{0,759} & 1 & $0,231^{* *}$ & 0,026 & $0,267^{* * *}$ & $0,285^{* *}$ & $0,179^{* * *}$ \\
\hline & & & & 0,000 & 0,615 & $\mathbf{0 , 0 0 0}$ & $\mathbf{0 , 0 0 0}$ & 0,001 \\
\hline \multirow{2}{*}{$\begin{array}{l}\text { Olumsuz } \\
\text { Kişilik } \\
\text { Eğilimi }\end{array}$} & \multirow{2}{*}{3,17} & \multirow[t]{2}{*}{0,622} & & 1 & $0,104^{*}$ & $\mathbf{0 , 2 0 3}^{* *}$ & 0,016 & $-0,003$ \\
\hline & & & & & 0,048 & $\mathbf{0 , 0 0 0}$ & 0,766 & 0,959 \\
\hline \multirow{2}{*}{$\begin{array}{l}\text { Olumlu } \\
\text { Kişilik } \\
\text { Eğilimi }\end{array}$} & \multirow[b]{2}{*}{$\begin{array}{l}2,6 \\
7\end{array}$} & \multirow[t]{2}{*}{0,745} & & & 1 & 0,047 & $0,147^{* * *}$ & $0,324^{* *}$ \\
\hline & & & & & & 0,375 & 0,005 & $\mathbf{0 , 0 0 0}$ \\
\hline \multirow{2}{*}{$\begin{array}{l}\text { Aranan } \\
\text { Anlam }\end{array}$} & \multirow{2}{*}{$\begin{array}{l}3,4 \\
7\end{array}$} & \multirow[t]{2}{*}{0,873} & & & & 1 & $0,249^{* *}$ & $\mathbf{0 , 2 1 2}^{* *}$ \\
\hline & & & & & & & 0.000 & 0,000 \\
\hline \multirow[t]{2}{*}{$\begin{array}{l}\text { Mevcut } \\
\text { Anlam }\end{array}$} & \multirow{2}{*}{3,41} & \multirow[t]{2}{*}{0,857} & & & & & 1 & $\mathbf{0 , 5 0 5}^{* *}$ \\
\hline & & & & & & & & 0,000 \\
\hline \multirow[t]{2}{*}{$\begin{array}{l}\text { Yaşam } \\
\text { Doyumu }\end{array}$} & \multirow[t]{2}{*}{2,97} & \multirow[t]{2}{*}{$\begin{array}{r}0,901 \\
83\end{array}$} & & & & & & 1 \\
\hline & & & & & & & & \\
\hline
\end{tabular}

Tablo 9'da görüldüğü gibi, araştırmada kullanılan değişkenler arasında en yüksek ortalamaya "Dürüst Kişilik Eğilimi”" boyutu sahiptir. En düşük ortalamaya ise "Olumlu Kişilik Eğilimi”" sahiptir. Dürüst kişilik eğilimi boyutu ortalaması 3,63 iken, olumlu kişilik eğilimi boyutu ortalaması 2,67'dir. Değişkenler arası korelasyon katsayılarına bakıldığında, dürüst kişilik eğilimi ile aranan anlam arasında pozitif yönlü anlamlı bir korelasyon $(\mathrm{r}=0,267)$ mevcuttur $(\mathrm{p}<0,05)$. Dürüst kişilik eğilimi arttıkça aranan anlam düzeyi de artmaktadır. Dürüst kişilik eğilimi ile mevcut anlam arasında pozitif yönlü anlamlı bir ilişki $(r=0,285)$ olduğu 
gözlenmiştir $(\mathrm{p}<0,05)$. Dürüst kişilik eğilimi arttıkça mevcut anlam düzeyi de artmaktadır. Dürüst kişilik eğilimi ile yaşam doyumu arasında pozitif yönlü anlamlı bir korelasyon $(r=0,179)$ mevcuttur $(p<0,05)$. Dürüst kişilik eğilimi arttıkça yaşam doyumu da artmaktadır. Olumsuz kişilik eğilimi ile aranan anlam arasında pozitif yönlü anlamlı bir ilişki $(r=0,203)$ vardır $(\mathrm{p}<0,05)$. Olumsuz kiş̧ilik eğilimi arttıkça aranan anlam düzeyi de artmaktadır. Olumlu kişilik eğilimi ile mevcut anlam arasında pozitif yönlü anlamlı bir korelasyon $(\mathrm{r}=0,147)$ olduğu gözlenmiştir $(\mathrm{p}<0,05)$. Olumlu kişilik eğilimi arttıkça mevcut anlam düzeyi de artmaktadır. Olumlu kişilik eğilimi ile yaşam doyumu arasında pozitif yönlü anlamlı bir ilişki $(r=0,324)$ mevcuttur $(p<0,05)$. Olumlu kişilik eğilimi arttıkça yaşam doyumu da artmaktadır. Aranan anlam ile yaşam doyumu arasında pozitif yönlü anlamlı bir korelasyon $(r=0,212)$ olduğu gözlenmiştir $(p<0,05)$. Aranan anlam düzeyi arttıkça yaşam doyumu da artmaktadır. Mevcut anlam ile yaşam doyumu arasında pozitif yönlü güçlü bir korelasyon $(r=0,505)$ mevcuttur $(\mathrm{p}<0,05)$. Mevcut anlam düzeyi arttıkça yaşam doyumu da artmaktadır.

\section{TARTIŞMA, SONUÇ VE ÖNERILER}

Öğrencilerin dürüst kişilik eğilimine sahip olmaları hem aranan anlam hem de mevcut anlam seviyelerini arttırmaktadır. Dürüst kişilik eğilimi yaşamın anlamı düzeyinin her iki alt boyutunu da pozitif ve anlamlı olarak etkilemektedir. $\mathrm{Bu}$ kapsamda dürüst kişilik eğiliminin yaşamın anlamı seviyesini arttıran önemli bir değişken olduğu söylenebilir. Öğrencilerin dürüst kişilik eğilimine sahip olmaları yaşam doyumlarını artmaktadır. Sonuç olarak dürüst kişilik eğiliminin hem yaşamın anlamı hem de yaşam doyumunu arttıran önemli bir unsur olduğu görülmektedir. $\mathrm{Bu}$ kapsamda dürüst kişilik eğilimine odaklanmak ve bu yönde faaliyetler sürdürmenin önemli olduğu ifade edilebilir.

Olumsuz kişilik eğilimi aranan anlam düzeyini arttırırken, olumlu kişilik eğilimi mevcut anlam düzeyini arttırmaktadır. Bu dikkat çeken bir sonuçtur. Olumsuz kişilik eğiliminin aranan anlam düzeyini yani kişinin aradığı anlamı arttırdığ1 söylenebilir. Olumlu kişilik eğiliminin mevcut anlamı yani var olan anlamı arttırdığı ifade edilebilir. Öğrencilerin olumlu kişilik eğilimine sahip olmaları yaşam doyumlarını arttırmaktadır. Sonuç olarak olumlu kişilik eğiliminin hem mevcut anlamı hem de yaşam doyumunu arttıran önemli bir unsur olduğu söylenebilir.

Ali ve Chamorro-Premuzic (2010), gerçekleştirdikleri araştırmalarında makyavelist eğilim düzeyi ile yaşam doyumu arasında negatif yönlü anlamlı bir korelasyon olduğunu belirlemiş̧lerdir. Araştırma sonuçlarında, belirtilen araştırmadan farklı olarak makyavelist kişilik eğilimi alt boyutlarından olumsuz kişilik eğilimi ile yaşam doyumu arasında anlamlı bir ilişki olmadığı belirlenmiştir. Ayrıca araştırma sonuçlarında, belirtilen araştırmadan farklı olarak makyavelist kişilik eğilimi alt boyutlarından dürüst kişilik eğilimi ve olumlu kişilik eğilimi ile yaşam doyumu arasında pozitif yönlü anlamlı bir ilişki olduğu gözlenmiştir.

Öğrencilerin aranan anlam seviyeleri arttıkça yaşam doyumları da artmaktadır. Öğrencilerin mevcut anlam seviyeleri arttıkça yaşam doyumları da artmaktadır. Mevcut anlam düzeyinin yaşam doyumu üzerine olan etkisi, aranan 
anlam düzeyinin etkisine göre oldukça fazladır. Başka bir deyişle mevcut anlam düzeyinin aranan anlam düzeyine göre yaşam doyumunu daha çok arttırdığ 1 gözlenmiştir. Sonuç olarak mevcut anlam düzeyinin yaşam doyumuna olan etkisinin daha önemli olduğu ortaya çıkmıştır.

Y1kılmaz ve Demir Güdül (2015), üniversite öğrencileri üzerine gerçekleştirdiği araştırmalarında yaşam doyumu ile mevcut anlam arasında pozitif yönlü anlamlı bir korelasyon olduğunu ve yaşam doyumu ile aranan anlam arasında negatif yönde anlamlı bir korelasyon olduğunu belirtmişlerdir. Yıkılmaz ve Demir Güdül (2015), mevcut anlam düzeyinin yaşam doyumunu anlamlı olarak etkilediğini ve aranan anlam seviyesinin yaşam doyumuna etkisi olmadığını belirlemiştir. Datu ve Mateo (2015) kolej öğrencileri üzerine gerçekleştirdikleri araştırmalarında mevcut anlam ile yaşam doyumu arasında pozitif yönlü anlamlı bir korelasyon olduğunu ve mevcut anlam düzeyinin yaşam doyumu üzerine pozitif yönlü bir etkisi olduğunu belirlemişlerdir. Datu ve Mateo (2015), aranan anlam ile yaşam doyumu arasında anlamlı bir korelasyon olmadığını ifade etmişlerdir. Eakman ve Eklund (2012) üniversite öğrencileri üzerine uyguladıkları araştırmada yaşamın anlamı ölçeğinin alt boyutu olan mevcut anlam ile yaşam doyumu arasında pozitif yönlü anlamlı bir korelasyon olduğunu belirlemişlerdir.

Araştırma sonuçlarında, belirtilen araştırmalar ile benzer olarak mevcut anlam düzeyinin yaşam doyumu üzerine pozitif yönlü anlamlı bir etkisi olduğu ve mevcut anlam ile yaşam doyumu arasında pozitif yönlü anlamlı bir korelasyon olduğu belirlenmiştir. Ancak araştırma sonuçlarında belirtilen araştırmalardan farklı olarak aranan anlam düzeyinin yaşam doyumu üzerine pozitif yönlü anlamlı bir etkisi olduğu ve aranan anlam ile yaşam doyumu arasında pozitif yönlü anlamlı bir korelasyon olduğu belirlenmiştir.

Pan vd. (2008) üniversite öğrencilerine uyguladıkları araştırmalarında yaşamın anlamı ile yaşam doyumu arasında pozitif yönlü anlamlı bir korelasyon olduğunu ve yaşamın anlamı seviyesinin yaşam doyumu üzerine pozitif anlamlı bir etkisi olduğunu belirlemişlerdir. Araştırmada, belirtilen çalışmaya benzer olarak yaşamın anlamı alt boyutları olan mevcut anlam ve aranan anlam ile yaşam doyumu arasında pozitif yönlü anlamlı bir korelasyon olduğu belirlenmiştir. Ayrıca araştırmada, belirtilen çalışmaya benzer olarak yaşamın anlamı alt boyutları olan mevcut anlam ve aranan anlam düzeyinin yaşam doyumu üzerine pozitif yönlü ve anlamlı bir etkisi olduğu saptanmıştır.

Sonuç olarak öğrencilerin dürüst ve olumlu kişilik eğiliminin desteklenmesi ve olumsuz kişilik eğilimine yönelik önlemler alınması önerilebilir. Üniversite öğrencilerinin yaşamın anlamı ve yaşam doyumunu arttıran dürüst kişilik eğilimi ve olumlu kişilik eğilimini geliştirici faaliyetler yürütülmesi önerilebilir. Buna ilave olarak öğrencilerin olumsuz kişilik eğilimi algılarını önleyici uygulama ve aktiviteler yürütülmesi önerilebilir. Bu konularda daha çok sosyal faaliyet ve uygulamalar gerçekleştirilmesi önerilebilir. 


\section{KAYNAKÇA}

Akın, A. ve Taş, İ. (2011), "The Validity and Reliability of the Turkish Version of the Meaning in Life Questionnaire", 3nd International Congress of Educational Research, 4-7 May, Antalya, Türkiye.

Akın, A. ve Taş, İ. (2015), Yaşam Anlamı Ölçeği: Geçerlik ve Güvenirlik Çalışması, Turkish Studies, Vol.10(3), Winter, 27-36.

Aktaş, H. ve Şimşek, E. (2014), Pozitif Psikoloji Bağlamında Türk Kültüründe Yaşamın Anlamı ve Yaşam Doyumunun Analizi: Neşet Ertaş Türküleri Örneği, Türk Dünyası Araştırmaları, Sayı 208, Şubat, 449-480.

Ali, F. ve Chamorro-Premuzic, T. (2010), The Dark Side of Love and Life Satisfaction: Associations with Intimate Relationships, Psychopathy and Machiavellianism, Personality and Individual Differences, 48, 228-233.

Alpar, R. (2011), Uygulamalı Çok Değişkenli Ístatistiksel Yöntemler, 3.Baskı, Detay Yayıncılık, Ankara.

Ayan, A., Ünsar, S. ve Kahraman, G. (2013), A Research on the Determination of Machiavellian Personality Tendencies, Eskişehir Osmangazi Üniversitesi Sosyal Bilimler Dergisi, Haziran, 14(1), 103-121.

Becker, J.A.H. ve Dan O'Hair, H. (2007), Machiavellians' Motives in Organizational Citizenship Behavior, Journal of Applied Communication Research, Vol.35, No.3, 246-267.

Christie, R. ve Geis, F. (1970), Studies in Machiavellianism, Academic Press, New York.

Çelik, M. (2016), Tükenmişlik Yaşam Doyumu ve İş Yükü İlişkisi: Denizli’de Faaliyet Gösteren Muhasebe Meslek Mensupları Üzerinde Bir Araştırma, Süleyman Demirel Üniversitesi İktisadi ve İdari Bilimler Fakültesi Dergisi, 21(4), 1139-1152.

Çokluk, Ö., Şekercioğlu, G. ve Büyüköztürk, Ş. (2012), Sosyal Bilimler İçin Çok Değişkenli İstatistik SPSS ve LISREL Uygulamalarl, 2. Bask1, Pegem Akademi, Ankara.

Datu, J.A.D. ve Mateo, N.J. (2015), Gratitude and Life Satisfaction among Filipino Adolescents: The Mediating Role of Meaning in Life, International Journal of Adv. Counselling, 37, 198206.

Demirbaş Çelik, N. ve İşmen Gazioğlu, E. (2015), Yaşamda Anlam Ölçeği Lise Formu: Türkçe Geçerlik ve Güvenirliği, Mehmet Akif Ersoy Üniversitesi Eğitim Fakültesi Dergisi, Mart, Say1 33, 42-60.

Demirbaş Çelik, N. (2016), Üniversite Öğrencilerinin Yaşamda Anlam ve Yaşam Amaçları Arasındaki İlişki, Mediterranean Journal of Humanities, VI/1, 133-141.

Diener, E., Emmons, R.A., Larsen, R.J. ve Griffin, S. (1985), The Satisfaction With Life Scale, Journal of Personality Assessment, 49,1, 71-75.

Eakman, A. M. ve Eklund, M. (2012), The Relative Impact of Personality Traits, Meaningful Occupation and Occupational Value on Meaning in Life and Life Satisfaction, Journal of Occupational Science, Vol. 19(2), June, 165-177.

Engeler, A. ve Yargıç, İ. (2004), Makyavellinizm (Mach-IV) Ölçeğinin Türkçe Uyarlamasının Güvenilirliği, 40. Ulusal Psikiyatri Kongresi, İzmir.

Güner, F., Çiçek, H. ve Can, A. (2014), Banka Çalışanlarının Mesleki Stres ve Tükenmişlik Düzeylerinin İş Doyumu ve Yaşam Doyumu Düzeyleri İle İlişkisi, Uluslararası Alanya İşletme Fakültesi Dergisi, Cilt 6, Sayı 3, 59-76.

Güney, S. ve Mandacı, G. (2009), Makyavelizm ve Etik Algısı İlişkileri: Bankacılık Sektöründe Bir Araştırma, H.Ü. İktisadi ve İdari Bilimler Fakültesi Dergisi, Cilt 27, Sayı 2, 83-104.

Gürel, E.B.B. ve Gürel, E. (2015), Muhasebe Meslek Mensuplarının Mesleki Tükenmişlik Düzeyinin Yaşam Doyumu Üzerine Etkisi: Aydın İli Örneği, Muhasebe ve Denetime Bakış, Ocak, 44, 37-47.

Kalaycı, Ş. (2010). SPSS Uygulamalı Çok Değişkenli İstatistik Teknikleri, 5. Baskı, Asil Yayın Dağıtım, Ankara.

Kanten, P., Yeşiltaş, M. ve Arslan, R. (2015), Kişiliğin Karanlık Yönünün Üretkenlik Karşıtı İş Davranışlarına Etkisinde Psikolojik Sözleşmenin Düzenleyici Rolü, Atatürk Üniversitesi Iktisadi ve İdari Bilimler Dergisi, Cilt 29, Say1 2, 365-391. 
Köker, S. (1991), Normal ve Sorunlu Ergenlerin Yaşam Doyumu Düzeylerinin Karşılaştırılması, Ankara Üniversitesi Sosyal Bilimler Enstitüsü, Basılmamış Yüksek Lisans Tezi, Ankara.

Lang, A. (2015), Borderline Personality Organization Predicts Machiavellian Interpersonal Tactics, Personality and Individual Differences, 80, 28-31.

Martela, F. ve Steger, M.F. (2016), The Three Meanings of Meaning in Life: Distinguishing Coherence, Purpose, and Significance, The Journal of Positive Psychology, http://dx.doi.org/10.1080/17439760.2015.1137623.

Mason, H.D. (2013), Meaning in Life Within an African Context: A Mixed Method Study, Journal of Psychology in Africa, 23(4), 635-638.

Pan, J.Y., Wong, D.F.K., Joubert, L. ve Chan, C.L.W. (2008), The Protective Function of Meaning of Life on Life Satisfaction Among Chinese Students in Australia and Hong Kong: A CrossCultural Comparative Study, Journal of American College Health, Vol. 57, No.2, 221-231.

Pavot, W. ve Diener, E. (2008), The Satisfaction With Life Scale and the Emerging Construct of Life Satisfaction, The Journal of Positive Psychology, Vol.3, No.2, April, 137-152.

Proctor, C., Linley, P.A. ve Maltby, J. (2009), Youth Life Satisfaction Measures: A Review, The Journal of Positive Psychology, Vol.4, No.2, March, 128-144.

Rauthmann, J.F. (2012), Towards Multifaceted Machiavellianism: Content, Factorial, and Construct Validity of a German Machiavellianism Scale, Personality and Individual Differences, 52, 345-351.

Rauthmann, J.F. ve Kolar, G.P. (2012), How "Dark" are the Dark Triad Traits? Examining the Perceived Darkness of Narcissism, Machiavellianism, and Psychopathy, Personality and Individual Differences, 53, 884-889.

Saruhan, Ş.C. ve Özdemirci, A. (2011), Bilim, Felsefe ve Metodoloji, 2. Bask1, Beta Yayınları, İstanbul.

Sipahi, B., Yurtkoru, E.S. ve Çinko, M. (2010), Sosyal Bilimlerde SPSS'le Veri Analizi, 3. Bask1, Beta Yayınları, İstanbul.

Steger, M.F., Frazier, P., Oishi, S. \& Kaler, M. (2006), "The Meaning in Life Questionnaire: Assessing the Presence of and Search for Meaning in Life", Journal of Counseling Psychology, 53(1), 80-93.

Steger, M.F., Oishi, S. ve Kashdan, T.B. (2009), Meaning in Life across the Life Span: Levels and Correlates of Meaning in Life from Emerging Adulthood to Older Adulthood, The Journal of Positive Psychology, Vol.4, No.1, 43-52.

Şahin, M., Aydın, B., Sarı, S.V., Kaya, S. ve Pala, H. (2012), Öznel İyi Oluşu Açıklamada Umut ve Yaşamda Anlamın Rolü, Kastamonu Eğitim Dergisi, Eylül, Cilt:20, No:3, 827-836.

Şimşek, E. ve Aktaş, H. (2014), Örgütsel Sessizlik ile Kişilik ve Yaşam Doyumu Etkileşimi: Kamu Sektöründe Bir Araştırma, Anadolu Üniversitesi Sosyal Bilimler Dergisi, 14(2), 121-136.

Ural Uslan, Y. (2016), Kamu Çalışanlarının İş Doyumu, Yaşam Doyumu ve Tükenmişlik Düzeylerinin Bazı Sosyo-Demografik Unsurlara Göre Değerlendirilmesi, Journal of Human Sciences, 13(2), 3354-3372.

Yıkılmaz, M. ve Demir Güdül, M. (2015), Üniversite Öğrencilerinde Yaşamda Anlam, Bilinçli Farkındalık, Algılanan Sosyoekonomik Düzey ve Yaşam Doyumu Arasındaki İlişkiler, Ege Ĕ̈itim Dergisi, 16, 2, 297-315.

Yüksel, R. (2012), Genç Yetişkinlerde Yaşamın Anlamı, Sakarya University Journal of Education, 2(2), 79-91. 


\section{SUMMARY}

There is a growing interest in the concepts of positive psychology in today's world. In this context, positive variables, such as the meaning in life and life satisfaction have increased in importance. Machiavellian personality tendency is a factor that is considered to be negative for the individuals. This study examines in what way the perceptivity of Machiavellian personality tendency influences the meaning in life and life satisfaction. Moreover, the effect of the level of meaning in life on life satisfaction was examined in the study. The research sample comprises a total of 365 students from schools of applied sciences at a state university. The population of the research covers all students studying at this state university. In this present study, the Mach IV scale which has a total of 20 questions was used to measure the tendency to be Machiavellian. There are 10 positive and 10 negative questions in this scale. The meaning in life scale is a form of 10 questions. In the study, life satisfaction scale consisting of 5 questions was utilized. Thus, responses were on a 5-point Likert scale. In the research, analyses were carried out using SPSS 21 statistical software package. In this context; frequency analysis, factor analysis, reliability test, multiple regression tests and correlation analysis were carried out. In this current study, firstly, frequency distribution was carried out in connection with university students' socio-demographic characteristics. Then factor analysis and reliability tests were applied to the data scales of Machiavellian personality tendency, meaning in life and life satisfaction. As a result of the factor analysis carried out on the scale of Machiavellian personality tendency, three sub-dimensions emerged. These dimensions were named as 'honest personality tendency', 'negative personality tendency' and 'positive personality tendency' respectively. Similarly, as a result of the factor analysis carried out on the scale of meaning in life, two sub-dimensions emerged. These dimensions were named as 'search of meaning' and 'presence of meaning'. Moreover, factor analysis was applied to the scale of life satisfaction and a single dimension emerged. This dimension was named as 'life satisfaction'. Then reliability tests were applied to the variables and it was observed that Cronbach's Alpha value was in an acceptable level.

In this present study, it was observed that honest personality tendency has a significant positive effect on search of meaning. Similarly, it was observed that negative personality tendency has a significant positive effect on search of meaning. The effect of honest personality tendency on search of meaning is greater than the effect of negative personality tendency. In the same way, it was observed that honest personality tendency has a significant positive effect on presence of meaning. Similarly, it was observed that positive personality tendency has a significant positive effect on presence of meaning. The effect of honest personality tendency on presence of meaning is greater than the effect of positive personality tendency. In addition, honest personality tendency has a significant positive effect on life satisfaction. It was observed that positive personality tendency has a significant positive effect on life satisfaction. The effect of positive personality tendency on life satisfaction is greater than the effect of honest personality 
tendency. Following this further, it was observed that the level of search of meaning has a significant positive effect on life satisfaction. It was observed that the level of presence of meaning has a significant positive effect on life satisfaction. The effect of the level of presence of meaning on life satisfaction is rather greater than the effect of the level of search of meaning. As a result, it can be suggested to promote honest and positive personality tendencies and take measures for negative personality tendencies. It can also be recommended to carry out activities that develop University students' honest and positive personality tendencies. In addition, it can be recommended to conduct preventive practices and activities for the students who have negative personality tendencies. It also should be advised to be performed more and more social activities and practices regarding these issues. 